\title{
Optimization of Lipase-Catalyzed Transesterification of Cotton Seed Oil for Biodiesel Production Using Response Surface Methodology
}

\author{
Ying Xia Li ${ }^{1 *}$ and Bing Xue Dong ${ }^{2}$ \\ ${ }^{1}$ Qingdao Agricultural University - Marine Science and Engineering College; Qingdao, Shandong - China. \\ ${ }^{2}$ NanyangNormalUniversity - School of Life Science and Technology; Nanyang, Henan - China.
}

\begin{abstract}
The aim of this work was to study the biodiesel production from cotton seed oil by lipase produced by Pichia guilliermondii lipase, which was immobilized onto hydrophobic magnetic particles (HMPs). The optimum reaction conditions were determined for lipase dosage, methanol-to-oil molar ratio, temperature and water content. Using response surface methodology, a quadratic polynomial equation was obtained for fatty acid methyl esters (FAMEs) content by multiple regression analysis. Verification experiments confirmed the validity of the predicted model. The optimal conditions for the enzymatic transesterification were temperature of $38.76 \square$, 31.3\% immobilized lipase, 10.4\% water content, and a methanol-to-oil molar ratio of 4.715:1. The gas chromatography-mass spectrometry showed that biodiesel was mainly composed of the methyl esters of hexadecanoic, 9,12-octadecadienoic and 9octadecadienoic acid.
\end{abstract}

Key words: Biodiesel, response surface methodology, lipase; cotton seed oil

\section{INTRODUCTION}

Due to the rise in demand for energy and deterioration of the eco-environment, developing clean and renewable sources of alternative energy attracts more attentions (Liu et al. 2012). Biodiesel is a processed fuel derived from the renewable resources such as vegetable oils and animal fats, which can replace a significant percentage of petroleum diesel because its physical and chemical properties and energy content are similar to those of petroleum diesel (Robles-Medina et al. 2009). Biodiesel is more clean than the petroleum diesel as the emission of particulates, $\mathrm{CO}$, and unburned hydrocarbons from biodiesel combustion are all lower than that those from petroleum diesel (Santori et al. 2012), therefore, it is theoretically a renewable, non-toxic and biodegradable diesel fuel
(Knothe 2010). Biodiesel is mono alkyl ester of long chain fatty acids produced via esterification and transesterification with small chain alcohols, principally methanol, or ethanol (Joshi et al. 2008). Biodiesel has been commercialized and utilized in many countries, including China, Americas and India. Methanol is commonly used as an acylacceptor because of its low cost and high conversion rate compared with other alcohols. Biodiesel is, hence, commonly referred to as fatty acid methyl esters (FAMEs). The biodiesel production can be carried out by different catalysts, which may be classified as chemical catalysts and enzymes (Nie et al. 2015). Conventional chemical methods used for biodiesel production have many drawbacks such as high-energy consumption and intensive use of chemicals. Therefore, many researches focus on lipase-catalyzed

*Author for correspondence: liyx108@163.com 
transesterification for biodiesel, which is clean and effective (Liu et al. 2012). The lipase-catalyzed transesterification can also eliminate the inherent problems associated with the use of chemical catalysts (Ting et al. 2008). The major barrier to the wider use of enzymatic transesterification is the cost of lipases. Therefore, the use of an immobilized enzyme could be a good choice as it can provide enzyme reusability, hence reduces operational costs. It can also reduce enzyme contamination and facilitate easy separation of the products (Sengupta et al. 2010). In addition, the stability, activity and reusability of enzymes can also be improved by immobilization. The immobilized lipase has been studied extensively for biodiesel production due to its faster reaction rate and much lower preparation cost. Several commercial immobilized lipases, such as Novozym 435 and Lipozyme RM IM, have been also used to catalyze the methanolysis of oils (Jin et al. 2013).

In order to obtain the maximum yield of biodiesel, the effect of four main parameters, including temperature, methanol to oil molar rate, amount of biomass and water content were investigated. The response surface methodology (RSM) was also used to analyze the optimum values and the properties of biodiesel were ainvestigated by GClinked mass spectrometry (GC-MS).

\section{MATERIAL AND METHODS}

\section{Material}

Free lipase (lipase activity 3, $270 \mathrm{LU} / \mathrm{mL}$ ) from Pichia guilliermondii, which was isolated from seawater from Qing dao was used in the present work. $P$. guilliermondii was cultivated in liquid medium (olive oil, $10 \mathrm{~mL}$, glucose $5.0 \mathrm{~g},\left(\mathrm{NH}_{4}\right)_{2} \mathrm{SO}_{4}$ $1.0 \mathrm{~g}, \mathrm{MgSO}_{4} .7 \mathrm{H}_{2} \mathrm{O} 0.5 \mathrm{~g}, \mathrm{~K}_{2} \mathrm{HPO}_{4} 1.0 \mathrm{~g}$, seawater $1000 \mathrm{~mL}$ ) at $28^{\circ} \mathrm{C}$ and $150 \mathrm{rpm}$ for $3 \mathrm{~d}$ to produce lipase.

\section{Immobilization of lipase}

$\mathrm{FeCl}_{3}(2.7 \mathrm{~g})$ and $\mathrm{FesSO}_{4} .12 \mathrm{H}_{2} \mathrm{O}(1.3 \mathrm{~g})$ were dissolved in $50 \mathrm{~mL}$ distilled water. After this, three $\mathrm{mol} / \mathrm{L} \mathrm{NaOH}$ was added to the solution until the $\mathrm{pH}$ of solution was 13.0 before incubating at $80^{\circ} \mathrm{C}$ for $2 \mathrm{~h}$. The magnetic particles collected from the solution were washed with distilled water until the $\mathrm{pH}$ of the decanted water became neutral. Ten grams magnetic particles was covered with $30 \mathrm{~mL}$ TEOS (tetraethoxysilane), $80 \mathrm{~mL}$ ethanol, $24 \mathrm{~mL}$ distilled water, and $28 \mathrm{~mL} \mathrm{NH} 4 \mathrm{OH}$ at room temperature for $18 \mathrm{~h}$. The magnetic particles were washed with distilled water. Then mixed with 100 $\mathrm{mL}$ ethanol and $100 \mathrm{~mL}$ glycerol prior to incubating at $85^{\circ} \mathrm{C}$. After that, $10 \mathrm{~mL}$ [3-(trimethoxysilyl) propyl] octadecyldimethylamonium chloride was added to the solution. After $2 \mathrm{~h}$, the resulting particles were collected and dried at $60^{\circ} \mathrm{C}$ for $2 \mathrm{~h}$.

Ten grams of HMP was added to the $1.0 \mathrm{~L}$ culture supernatant at room temperature, and stirred by a magnetic stirrer at $4^{\circ} \mathrm{C}$ for $6 \mathrm{~h}$. The supernatant was separated from the solid material by centrifugation, and the solid material was washed with phosphate buffer ( $\mathrm{pH}$ 6.5). After that, the particles were lyophilized at $55^{\circ} \mathrm{C}$ and $10 \mathrm{~Pa}$ for $36 \mathrm{~h}$.

\section{General procedure for enzymatic transesterification}

The transesterification reactions were carried out in covered shaking flasks and heated to reaction temperature on a reciprocal shaker. The standard reaction mixture were consisted of oil, water, methanol and immobilized lipases. Samples $(100 \mu \mathrm{L})$ were taken after $48 \mathrm{~h}$ and centrifuged to obtain the upper layer. Five-microliter samples were mixed with $95 \mu \mathrm{L}$ of hexane and $300 \mu \mathrm{L}$ of internal standard solution (heptadecanoic acid methyl ester hexane solution) for gas chromatographic analysis. All the experiments were replicated at three times. Results presented were the mean values for the replicated data.

\section{Content of FAMEs}

The content of FAMEs in the reaction mixture was analyzed using a GC-14B gas chromatograph equipped with an FFAP capillary column (0.32 $\mathrm{mm} \times 25 \mathrm{~m}$ ) and an FID detector. The column temperature was set at $150^{\circ} \mathrm{C}$ for $0.5 \mathrm{~min}$, raised to $250^{\circ} \mathrm{C}$ at $15^{\circ} \mathrm{C} / \mathrm{min}$ and kept at this temperature for $10 \mathrm{~min}$. The temperatures of the injector and detector were set at 245 and $250^{\circ} \mathrm{C}$, respectively. Nitrogen at $70 \mathrm{~mL} / \mathrm{min}$ was used as the carrier gas. The pentadecanoic acid (C15:0, Sigma) methyl ester at $2.0 \mathrm{mg} / \mathrm{mL}$ was used as the internal standard. The conversion rate of biodiesel was calculated as the percentage by weight of fatty acid methyl esters formed divided by the weight of feed stock initially taken for the reaction.

\section{RSM experimental design}

The three-level four-factor D-Optimal design and RSM were employed in this study, totally requiring 27 experiments. A Box-Behnken design was used 
to study the response $\mathrm{Y}$, namely, methyl conversion. The parameters of four independable variables were $X_{1}, X_{2}, X_{3}$ and $X_{4}$ representing methanol-to-oil ratio ( $\mathrm{mol} / \mathrm{mol})$, amount of lipase to oil (w/w), water content $(\mathrm{v} / \mathrm{v})$ and reaction temperature $\left({ }^{\circ} \mathrm{C}\right)$, respectively. The settings for the independent variables were as follows (low/ high value): methanol molar ratio $3: 1,4.5: 1,6: 1$ ), immobilized enzyme amount $(0.2,0.3,0.4)$, water content $(0.05,0.1,0.15)$ and reaction temperature $\left(30,40,50{ }^{\circ} \mathrm{C}\right)$. Each variable to be optimized was coded at three levels $-1,0,+1$. The RSM was employed to evaluate the effect of reaction time, reaction temperature, immobilized enzyme and oil: alcohol ratio on FAMEs yield. The coded values for the variables are shown in Table 1 . In order to avoid bias, 27 runs were performed in random order.

Table 1 - The independent variables and levels used for response surface design.

\begin{tabular}{lllcc}
\hline Factors & symbol & & \multicolumn{2}{c}{ coded levels } \\
\cline { 3 - 5 } & & -1 & 0 & +1 \\
\hline Methanol to oil mole rate $(\mathrm{mol} / \mathrm{mol})$ & $\mathrm{X}_{1}$ & 3 & 4.5 & 6 \\
Immobilized lipase amount $(\mathrm{w} / \mathrm{w})$ & $\mathrm{X}_{2}$ & 0.2 & 0.3 & 0.4 \\
Water content (w/w) & $\mathrm{X}_{3}$ & 0.05 & 0.1 & 0.15 \\
Temperature $(\mathrm{C})$ & $\mathrm{X}_{4}$ & 30 & 40 & 50 \\
\hline
\end{tabular}

The responses were analyzed for the optimization for methyl ester conversion using SPSS 16.0 and Matlab R 2009b software. The quadratic polynomial regression model was assumed for predicting response. The empirical formula to find the optimal biodiesel yield was given by the Equation 1:

$\mathrm{Y}=\mathrm{A}_{0}+\mathrm{A}_{1} \mathrm{X}_{1}+\mathrm{A}_{2} \mathrm{X}_{2}+\mathrm{A}_{3} \mathrm{X}_{3}+\mathrm{A}_{4} \mathrm{X}_{4}+\mathrm{A}_{5} \mathrm{X}_{1} \mathrm{X}_{2}+\mathrm{A}_{6} \mathrm{X}_{1} \mathrm{X}_{3}+$ $\mathrm{A}_{7} \mathrm{X}_{1} \mathrm{X}_{4}+\mathrm{A}_{8} \mathrm{X}_{2} \mathrm{X}_{3}+\mathrm{A}_{9} \mathrm{X}_{2} \mathrm{X}_{4}+\mathrm{A}_{10} \mathrm{X}_{3} \mathrm{X}_{4}+\mathrm{A}_{11} \mathrm{X}_{1}^{2}+$ $\mathrm{A}_{12} \mathrm{X}_{2}^{2}+\mathrm{A}_{12} \mathrm{X}_{3}^{2}+\mathrm{A}_{14} \mathrm{X}_{4}{ }^{2}$

Where $Y$ was the percentage of fatty acid methyl esters (FAMEs) yield; $A_{0}$ was constant; $A_{1}, A_{2}, A_{3}$ and $\mathrm{A}_{4}$ were linear coefficients; $\mathrm{A}_{5}, \mathrm{~A}_{6}, \mathrm{~A}_{7}, \mathrm{~A}_{8}, \mathrm{~A}_{9}$ and $\mathrm{A}_{10}$ were cross-product coefficients; $\mathrm{A}_{11}, \mathrm{~A}_{12}$, $\mathrm{A}_{13}$ and $\mathrm{A}_{14}$ were quadratic coefficients, and $\mathrm{X}_{1}, \mathrm{X}_{2}$, $\mathrm{X}_{3}$ and $\mathrm{X}_{4}$ were the quadratic coefficients showing the squared effects.

The fitness of the model was analyzed by the coefficient of determination $(\mathrm{R})$ and its regression coefficient significance was checked by $\mathrm{F}$ test. In addition, the response surfaces and contour plots were developed by using the fitted quadratic polynomial equation obtained from regression analysis, holding two of the independent variables at constant value corresponding to the stationary point and changing the other two variables. Confirmatory experiments were employed to validate the equations by combinations of independent variables, which were not part of the original experimental design but were within the experimental region.

\section{Composition Analysis of Biodiesel}

The composition of biodiesel from cotton seed oil was analyzed by Thermo trace GC-MS (DSQ II ), equipped with a Varian VF-5ms column. The temperature of ion source was $250^{\circ} \mathrm{C}$. The scanning range was from 45 to 450 .

\section{RESULTS AND DISCUSSION}

\section{RSM Model Fitting}

The design of experiment matrix for the immobilized catalysts is illustrated in Table 2 . The maximum FAMEs yield was $89.32 \%$ (run 25), and minimum FAMEs yield was $40.79 \%$ (run 18). In addition, the experimental results of this analysis were used to develop a linear equation, which showed the relationships between FAMEs conversion percentage, molar ratio of methanol to oil, reaction temperature, water and catalyst concentration. The following polynomials were the regression equations presenting the result of modeling experimental data.

$\begin{array}{lrrr}Y=-564.392+ & 91.055 X_{1}+ & 778.908 X_{2}+ & 1128.7 X_{3}+ \\ 13.299 X_{4-} & 47.467 X_{1} X_{2}+ & 117.7 X_{1} X_{3-} & 0.035 X_{1} X_{4-} \\ 1315 X_{2} X_{3}+ & 2.71 X_{2} X_{4-} & 12.88 X_{3} X_{4-} & 9.24 X_{1}^{2}{ }^{2} \\ 836.208 X_{2}^{2}-3706.333 X_{3}^{2}-0.163 X_{4}^{2} & \end{array}$

The regression Eq. (2) was analyzed by MATLAB 7.0 software. The optimum parameters were 4.715 molar ratio of methanol to oil, temperature $38.7731^{\circ} \mathrm{C}, 0.3128$ immobilized lipase and 0.1043 water content based on cotton seed oil volume. The results of ANOVA for the predicted values fit well with the experimental values (Table 3). The goodness of fit of the model was predicted by the determination of the coefficient value of 0.976 and the adjusted $R^{2}$ values of 0.953 . The predicted value was also in good agreement with the adjusted $\mathrm{R}^{2}$ value, implying the significance of the model. The value 0.953 implied that the sample variation of 0.953 for FAMEs yield production was attributed to the independent variables, and only 0.047 of the total variation was not explained by the model.

Table 2 - D-Optimal design and response. 


\begin{tabular}{llllll}
\hline Design point & \multicolumn{4}{l}{ Coded independent variable levels } & Response \\
\cline { 2 - 5 } & $\mathrm{X}_{\mathrm{s}}$ & $\mathrm{X}_{\mathrm{s}}$ & $\mathrm{X}$ & $\mathrm{X}_{\mathrm{s}}$ & $\mathrm{Y}(\%)$ \\
\hline 1 & 3 & 0.2 & 0.1 & 40 & 43.56 \\
2 & 3 & 0.4 & 0.1 & 40 & 66.72 \\
3 & 6 & 0.2 & 0.1 & 40 & 67.73 \\
4 & 6 & 0.4 & 0.1 & 40 & 62.41 \\
5 & 4.5 & 0.3 & 0.05 & 30 & 55.29 \\
6 & 4.5 & 0.3 & 0.05 & 50 & 70.12 \\
7 & 4.5 & 0.3 & 0.15 & 30 & 70.23 \\
8 & 4.5 & 0.3 & 0.15 & 50 & 59.3 \\
9 & 3 & 0.3 & 0.1 & 30 & 52.67 \\
10 & 3 & 0.3 & 0.1 & 50 & 39.87 \\
11 & 6 & 0.3 & 0.1 & 30 & 63.2 \\
12 & 6 & 0.3 & 0.1 & 50 & 48.3 \\
13 & 4.5 & 0.2 & 0.05 & 40 & 62.34 \\
14 & 4.5 & 0.2 & 0.15 & 40 & 75.56 \\
15 & 4.5 & 0.4 & 0.05 & 40 & 78.45 \\
16 & 4.5 & 0.4 & 0.15 & 40 & 65.37 \\
17 & 3 & 0.3 & 0.05 & 40 & 58.36 \\
18 & 3 & 0.3 & 0.15 & 40 & 40.79 \\
19 & 6 & 0.3 & 0.05 & 40 & 57.49 \\
20 & 6 & 0.3 & 0.15 & 40 & 75.23 \\
21 & 4.5 & 0.2 & 0.1 & 30 & 64.13 \\
22 & 4.5 & 0.2 & 0.1 & 50 & 50.27 \\
23 & 4.5 & 0.4 & 0.1 & 30 & 71.12 \\
24 & 4.5 & 0.4 & 0.1 & 50 & 68.1 \\
25 & 4.5 & 0.3 & 0.1 & 40 & 89.32 \\
26 & 4.5 & 0.3 & 0.1 & 40 & 88.79 \\
27 & 4.5 & 0.3 & 0.1 & 40 & 87.23 \\
\hline & & & & &
\end{tabular}

Table 3 - Analysis of variance (ANOVA) for the fitted quadartic polynomial model.

\begin{tabular}{ccccc}
\hline Model & Sum of Squares & df & Mean square & F \\
\hline Regression & 4489.389 & 14 & 320.671 & 17.410 \\
Residual & 221.024 & 12 & 18.419 & \\
Total & 4710.421 & 26 & & \\
\hline $\mathrm{R}^{2}=0.976, \quad$ Adj R ${ }^{2}=0.953$ & & & \\
${ }^{* *}$ Significant at $1 \%$ level & & & \\
\hline
\end{tabular}

The regression coefficients and the corresponding significance are presented in Table 4. From the $\rho$ values of each model term, most of the coefficients were significant at $1 \%$ level, including of all the linear terms, the quadratic terms and the interaction of $X_{1} X_{2}$ and $X_{1} X_{3}$. The interaction terms of $X_{1} X_{4}$ and $\mathrm{X}_{3} \mathrm{X}_{4}$ were significant at the $5 \%$ level. Other terms of the model had no significant effects on FAMEs yield.

There are many parameters, which can influence the performance of FAMEs conversion from cotton seed oil. FAMEs conversion had a complex relationship with independent variables that encompassed both first and second-order polynomials. The best way of expressing the effect of all parameter on the FAMEs yield within the experimental parameters under investigated was to generate response surface plots of the equation.

Table 4 - Estimated regression coefficient for experimental yield (\%).

\begin{tabular}{clccc}
\hline Tem & \multicolumn{1}{c}{ Coefficient } & Standard error & $T$ value & $P_{\text {value }}$ \\
\hline Constant & -564392 & & -8.131 & 0.000 \\
$\mathrm{X}_{1}$ & 91.055 & 6.894 & 8.48 & 0.000 \\
$\mathrm{X}_{2}$ & 778.908 & 3.931 & 4.836 & 0.000 \\
$\mathrm{X}_{3}$ & 1128.7 & 2.848 & 3.864 & 0.002 \\
$\mathrm{X}_{4}$ & 13299 & 6.713 & 739 & 0.000 \\
$\mathrm{X}_{1} \mathrm{X}_{2}$ & -47.467 & -1539 & -3.318 & 0.006 \\
$\mathrm{X}_{1} \mathrm{X}_{3}$ & 117.7 & 1.627 & 4.114 & 0.001 \\
$\mathrm{X}_{1} \mathrm{X}_{4}$ & -0.035 & -0.133 & -0.245 & 0.811 \\
$\mathrm{X}_{2} \mathrm{X}_{3}$ & -1315 & -1212 & -3.064 & 0.010 \\
$\mathrm{X}_{2} \mathrm{X}_{4}$ & 2.71 & 0.688 & 1.263 & 0.231 \\
$\mathrm{X}_{3} \mathrm{X}_{4}$ & -12.88 & -1.466 & -3.001 & 0.011 \\
$\mathrm{X}_{1}{ }^{2}$ & -9.24 & -6345 & -11.188 & 0.000 \\
$\mathrm{X}_{2}{ }^{2}$ & -836208 & -2552 & -4.500 & 0.001 \\
$\mathrm{X}_{3}{ }^{2}$ & -3706.333 & -1903 & -4.986 & 0.000 \\
$\mathrm{X}_{4}{ }^{2}$ & -0.163 & -6.593 & -8.748 & 0.000 \\
\hline
\end{tabular}

The three dimensional response surfaces were plotted as shown in Figure 1 as a function of the interactions of any two of the variables by holding the other one at middle value. From the shape of contour plots, the significance of the mutual interactions between the independent variables could be estimated. An elliptical profile of the contour plots indicates remarkable interaction between the independent variables. The Figure 1 showed similar relationships with respect to the effects of each variable. The response obtained were convex nature suggesting that there were welldefined optimum operating conditions. The FAMEs yields were sensitive to the methanol molar ratio, water content, temperature and enzyme amount.

Figure 1A showed the interaction of lipase amount and methanol molar rate on FAMEs conversion. The molar ratio of ethanol to oil was one of the most important variables affecting FAMEs conversion. The FAMEs yield initially increased as the increasing of methanol. The stoichiometric ratio for methanol to oil was 3:1. While the methanol molar ratio higher than theoretical value could drive the reaction to completion in practice. In this study, the highest conversion was obtained at the 4.715: 1 molar ratio. Whereas, continuing the increase in the molar ratio led to a decrease in the yield in that unresolved methanol, which deactivated the lipase by destroying the active centers of enzyme ( $\mathrm{Li}$ et al. 2013). This could be due to fact that methanol was a denaturing agent of enzymes and insoluble in the oil at high concentration, which made proteins unstable and deprived "indispensable water" of enzyme (Qin et al. 2008). The amount of water associated with the enzyme is usually an important factor in the process of lipase-catalyzed transesterification. Therefore, the effect of water content on transesterification was also examined. 
As shown in Figure 1B, increasing the water content from 0.05 to 0.15 , the FAMEs yield initially increased. Nonetheless, continuing the increase in the molar ratio led to a decrease in the yield. Water plays multiple roles during lipase catalyzed methanolysis. Water strongly influences the catalytic activity and stability of the lipase, and is essential to keep the enzyme active in organic solvents. The hydrolysis of oil to fatty acids is activated when the water is abundant due to the increase in the available interfacial area.

The interaction of water content and lipase amount on FAMEs conversion was shown in Figure 1C. The lipase usually catalyzes hydrolysis of oil in the aqueous solution; therefore, the increase in interfacial area would stimulate the competing hydrolysis reaction, and further retarding the transesterification reactions (Al-Zuhair et al. 2007). Interaction of water content and temperature on FAMEs conversion is shown in Figure 1D. In this study, the temperature range was $30-50^{\circ} \mathrm{C}$. Figure 1d showed that raising the temperature initially boosted the yield and then caused a reduction. Increasing the temperature resulted in an increase in FAMEs yield. Temperature is a key parameter that affects the conformation of lipase and the reaction rate. The reaction is slow at a low temperature. However, too high temperature induces an increase in the rate of reaction diminishing the stability of enzyme (Gaderinezhad et al. 2014). Therefore, the optimum temperature hinges on the interplay between the operational stability of enzymes and the reaction rate (Mahapatra et al. 2009).

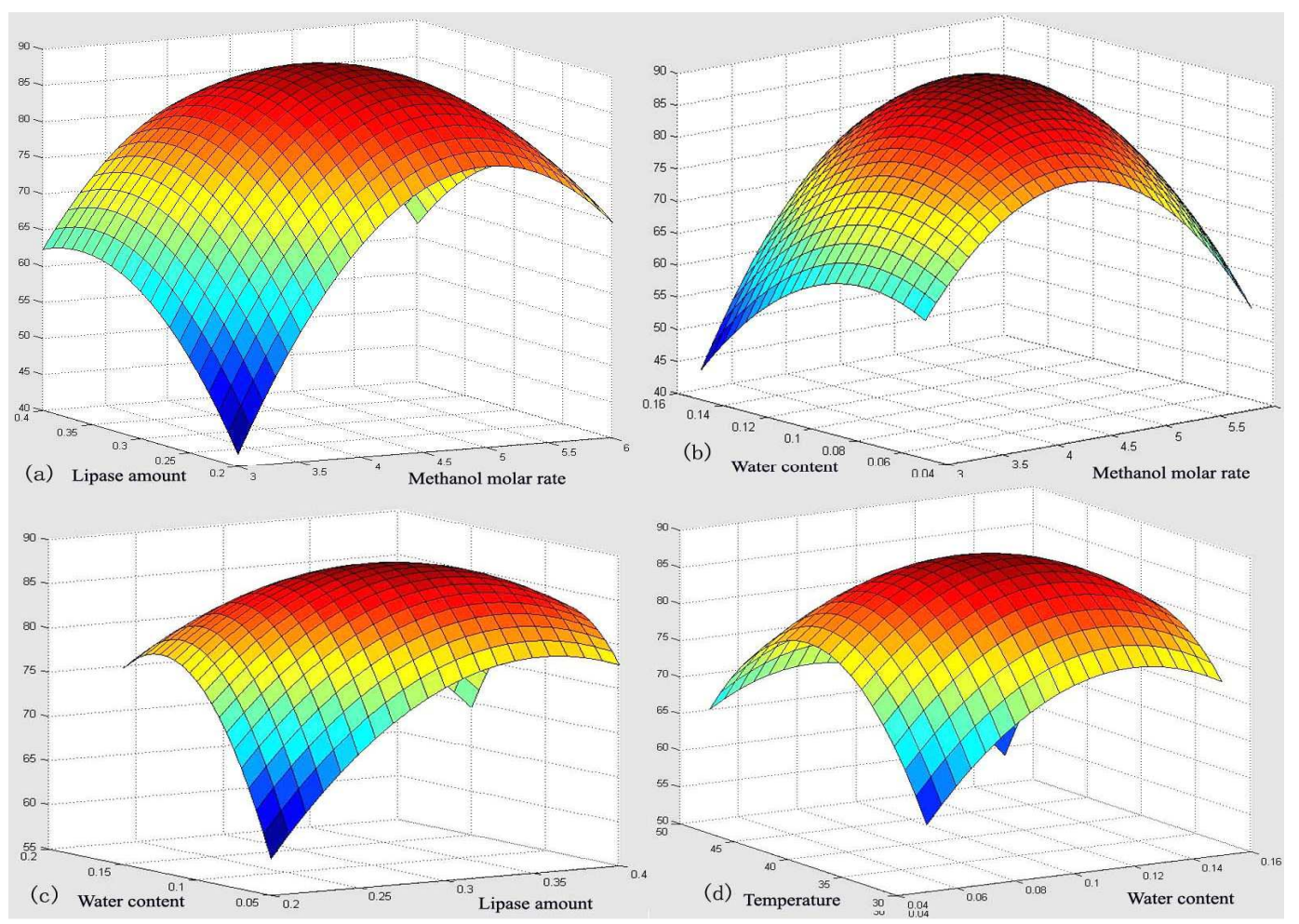

Figure 1 - 3D surface plots of the combined effect of the lipase amount and methanol molar rate (A), water content and methanol molar rate (B), water content and lipase amount $(\mathrm{C})$, temperature and water content (D).

\section{Qualitative Analysis of FAMEs}

Chromatogram of biodiesel from cotton oil (Fig. 2A) showed that there were seven fatty acid methyl esters, which were further analyzed with MS. The composition of the biodiesel analyzed by GC-MS suggested that cotton seed oil biodiesel was composed of methyl tetradecanoate $\left(\mathrm{C}_{15} \mathrm{H}_{30} \mathrm{O}_{2}\right)$, hexadecanoic acid methyl ester $\left(\mathrm{C}_{17} \mathrm{H}_{34} \mathrm{O}_{2}\right), 9,12-$ octadecadienoic acid methyl ester $\left(\mathrm{C}_{19} \mathrm{H}_{34} \mathrm{O}_{2}\right)$ and 9- octadecadienoic acid methyl ester $\left(\mathrm{C}_{19} \mathrm{H}_{36} \mathrm{O}_{2}\right)$, Octadecadienoic acid methyl ester $\left(\mathrm{C}_{19} \mathrm{H}_{38} \mathrm{O}_{2}\right), 11$ Eicosenoic acid methyl ester $\left(\mathrm{C}_{21} \mathrm{H}_{40} \mathrm{O}_{2}\right)$ and Eicosenoic acid methyl ester $\left(\mathrm{C}_{21} \mathrm{H}_{42} \mathrm{O}_{2}\right)$. The MS spectra of three main fatty acid methyl esters, 
including hexadecanoic acid methyl ester $\left(\mathrm{C}_{17} \mathrm{H}_{34} \mathrm{O}_{2}\right)$, 9, 12- octadecadienoic acid methyl ester $\left(\mathrm{C}_{19} \mathrm{H}_{34} \mathrm{O}_{2}\right)$ and 9- octadecadienoic acid methyl ester $\left(\mathrm{C}_{19} \mathrm{H}_{36} \mathrm{O}_{2}\right)$ are shown in Figures $2 \mathrm{~A}$, $2 \mathrm{~B}, 2 \mathrm{C}$, respectively.
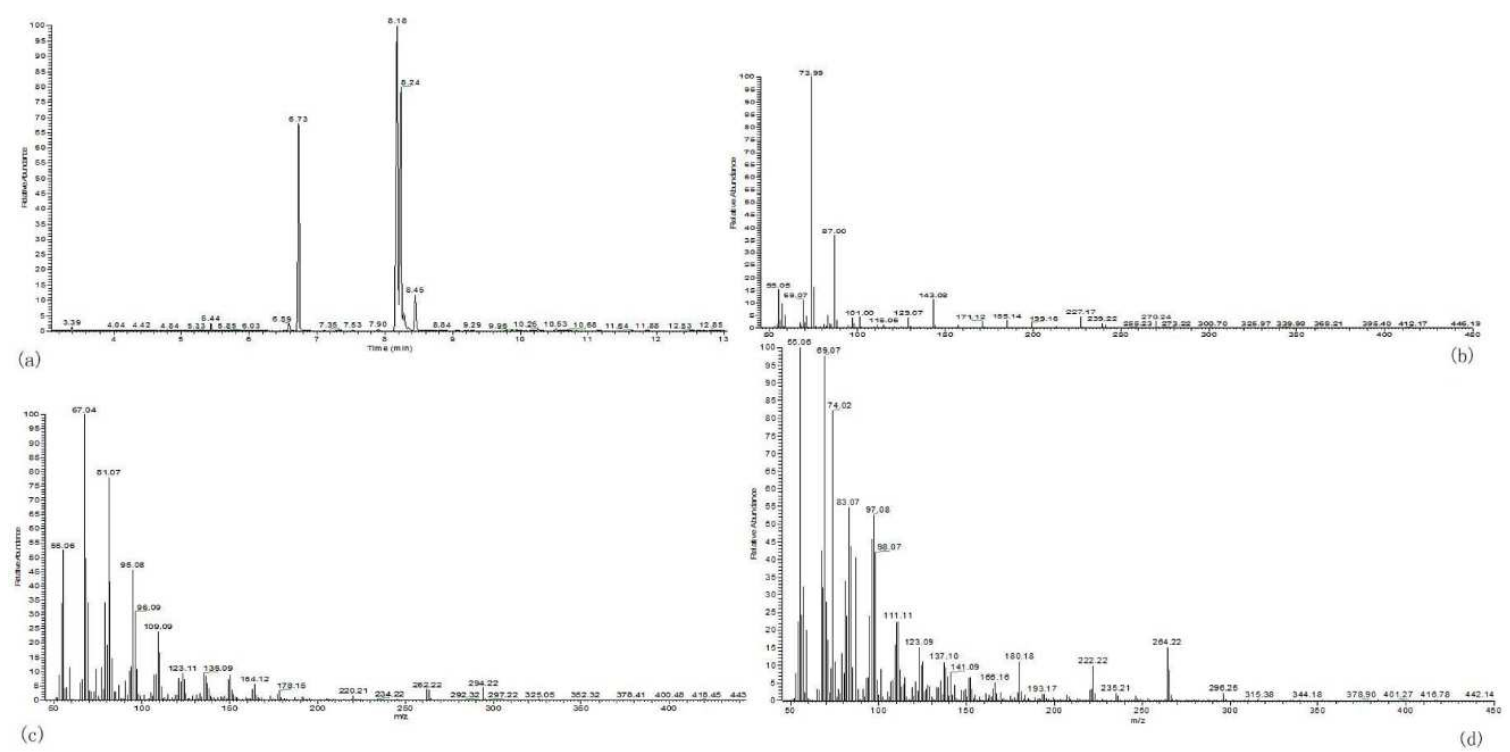

Figure 2 - GC-MS of biodiesel from cotton seed oil. Gas chromatography spectrum of FAMEs (A); mass spectra of hexadecanoic acid methyl ester (B), 9,12-octadecadienoic acid methyl ester (C), and 9-octadecadienoic acid methyl ester (D).

Three main components made up more than $94 \%$ of the total biodiesel. Other minor methyl esters were also analyzed and shown in Table 5.

Table 5 - The retention times and content of each fatty acid methyl ester in biodiesel from cotton seed oil.

\begin{tabular}{lll}
\hline Faty acid methyl ester content $(\%)$ & Renton time (min) & Content $(\%)$ \\
\hline Methyl tetrade canoate $\left(\mathrm{C}_{15} \mathrm{H}_{30} \mathrm{O}_{2}\right)$ & 5.44 & 0.56 \\
7-Hex adecanoic acid mehtyl ester $\left(\mathrm{C}_{1}, \mathrm{H}_{32} \mathrm{O}_{2}\right)$ & 6.59 & 0.72 \\
Hex adecanoic acid mehtyl ester $\left(\mathrm{C}_{1}, \mathrm{H}_{34} \mathrm{O}_{2}\right)$ & 6.73 & 20.21 \\
9,12-Octadecadienoicacid methyl ester $\left(\mathrm{C}_{13} \mathrm{H}_{34} \mathrm{O}_{2}\right)$ & 8.18 & 42.72 \\
9- Octadecadienoic acid methyl ester $\left(\mathrm{C}_{15} \mathrm{H}_{35} \mathrm{O}_{2}\right)$ & 8.24 & 31.09 \\
Octadecadienoic acid methyl ester $\left(\mathrm{C}_{15} \mathrm{H}_{35} \mathrm{O}_{2}\right)$ & 8.45 & 4.00 \\
11-Eicosenoic acid methyl ester $\left(\mathrm{C}_{21} \mathrm{H}_{40} \mathrm{O}_{2}\right)$ & 10.26 & 0.40 \\
Eicosenoic acid methyl ester $\left(\mathrm{C}_{22} \mathrm{H}_{42} \mathrm{O}_{2}\right)$ & 10.53 & 0.30 \\
\hline
\end{tabular}

Polyunsaturated fatty acids contain one, or more double bonds, which were susceptible to oxidation during the storage, thus reduced the acceptability for the production of biodiesel ( $\mathrm{Li}$ et al. 2011). The GC-MS study demonstrated that the biodiesel from cotton seed oil contained mainly saturated and mono-unsaturated fatty acids ( $75 \%$ of the total fatty acyl methyl esters), which advocated its high oxidative stability. Therefore, cotton seed oil could be considered as a potential organism for biodiesel production.

\section{CONCLUSIONS}

In this study, water was used as the reaction medium for the preparation of biodiesel production through the immobilized lipase-catalyzed transesterification of cotton seed oil and methanol. The optimal conditions was 4.715 molar ratio of methanol to oil, temperature $38.7^{\circ} \mathrm{C}, 31.27 \%$ immobilized lipase and $10.43 \%$ water content based on cotton seed oil volume by RSM analysis. The GC-MS showed that biodiesel was mainly composed of the methyl esters of hexadecanoic, 9, 12- octadecadienoic and 9- octadecadienoic acid.

\section{ACKNOWLEDGMENTS}

This work was financially supported by the Advanced Talents Foundation of Qingdao Agricultural University (No.1114349).

\section{REFERENCES}


Ghaderinezhad F, Kariminia HR, Yaghmaei S. Production of biodiesel from waste frying oil using whole cell biocatalysts: optimization of effective factors. Waste Biomass Valor. 2014; 5: 947-954.

Jin Z, Han SY, Zhang L, Zheng SP, Wang Y, Lin Y. Combined utilization of lipase-displaying Pichia pastoris whole-cell biocatalysts to improve biodiesel production in co-solvent media. Bioresource Technol. 2013; 130: 102-109.

Knote G. Biodiesel and renewable diesel: a comparison. Pro Engery Combust. 2010; 36: 364-373.

Li YX, Yang JW, Hui FL, Fan WW, Yang Y. Optimization of biodiesel production from rice bran oil via immobilized lipase catalysis. Afr J Biotechnol. 2011; 10(72):16314-16324.

Li YX, Yu DD, Wang Y, Guan XL. Response surface methodology optimization of lipase-catalyzed transesterification of Jatropha Curcas L. seed oil for biodiesel production. Biotechnol Equip. 2013; 27(6): 4284-4289.

Liu CH, Huang CC, Wang YW, Lee DJ, Chang JS. Biodiesel production by enzymatic transesterification catalyzed by Burkholderia lipase immobilized on hydrophobic magnetic particles. Appl Energ. 2012, 100:41-46.

Liu CZ, Wang F, Stiles AR, Guo C. Ionic liquids for biofuel production: opportunities and challenges. Appl Energy. 2012;92:406-414.

Mahapatra P, Kumari A, Garlapati VK, Banerjee R, Nag A. Enzymatic synthesis of fruit flavor esters by immobilized lipase from Rhizopus oligosporus optimized with response surface methodology. Mol Catal B: Enzym. 2009; 60: 57-63.

Nie K, Wang M, Zhang X, Hu WJ, Liu L, Wang F, et al. Additives improve the enzymatic synthesis of biodiesel from waste oil in a solvent free system. Fuel. 2015; 146:13-19.

Qin HE, Xu Y, Teng Y, Wang D. Biodiesel production catalyzed by whole-cell lipase from Rhizopus chinensis. Chin J Catal. 2008; 29(1): 41-46.

Robles-Medina A, Gonzalez-Moreno PA, EstebanCerdan L, Molina-Grima E. Biocatalysis: towards ever greener biodiesel production. Biotechnol Adv. 2009; 27:198-408.

Sengupta A, Pal M, SilRoy S, Ghosh M. Comparative Study of Sterol Ester Synthesis using Thermomyces lanuginosus Lipase in Stirred Tank and Packed-Bed Bioreactors. J Am Oil Chem Soc. 2010; 87(9): 10191025.

Ting WJ, Huang CM, Giridhar N, Wu WT. An enzymatic/acid-catalyzed hybrid process for biodiesel production from soybean oil. J Chin Inst Chem Eng. 2008; 39: 203-210. 